\title{
The contemporary role of trade unions in the European Union in comparison with Macedonia, Serbia and Croatia
}

\begin{abstract}
Trade unions have always been a tool for the protection and advancement of workers' rights. At EU level, trade unions are represented in various levels and institutions and are significantly involved in the decision-making process either directly or indirectly. In Macedonia, Serbia and Croatia, as ex-socialist countries, trade unions have more or less conserved their role from the previous system and are still, to a greater or lesser extent, 'under the hat' of the political parties in power, which are always eager to exercise some kind of control over the key positions. Trade unions in these countries still have weak management capacity and a lack of finances; the social dialogue is weak; and they are marginalised in the decision-making process. This article makes a comparison using contemporary observation of the current role of trade union organisations in the EU and in Macedonia (in the main), as well as in Serbia and Croatia, and of the impact they have on domestic decision-making processes.
\end{abstract}

Keywords: trade unions, workers, EWCs, European legislation, information and communication, European institutions, protest actions, austerity, collective labour law, social dialogue, capacity gaps, strike

Introduction

In the present times of serious economic and financial crisis in Europe and the world, where governments face major budgetary deficits and enormous public debt, the austerity measures taken by governments often affect the everyday life of workers across Europe in a particularly serious way. Especially in such conditions, the position and activities of trade unions and employee associations are of vital importance in order to tackle and lessen the negative impacts of these measures on workers' standards of living, as well as to offer suitable and more rigorous alternatives to these measures.

This article will be focused on the position and recent activities of trade unions in the EU, especially the ETUC, as well as the position and recent activities of trade unions in Macedonia, Serbia and Croatia.

The role of trade unions in the European Union

Historically, freedom of association at the European level was recognised by the European Convention on Human Rights and the complementary European Social Charter, which was revised in 1996. Under Article 11(1) of the ECHR: 
Everyone has the right to freedom of peaceful assembly and to freedom of association with others, including the right to form and to join trade unions for the protection of his interests.

The European Social Charter provides in Part I that:

All workers and employers have the right to freedom of association in national or international organisations for the protection of their economic and social interests.

All workers and employers have the right to bargain collectively.

Furthermore, Article 5 of Part II provides that:

With a view to ensuring or promoting the freedom of workers and employers to form local, national or international organisations for the protection of their economic and social interests and to join those organisations, the Contracting Parties undertake that national law shall not be such as to impair, nor shall it be so applied as to impair, this freedom. The extent to which the guarantees provided for in this article shall apply to the police shall be determined by national laws or regulations. The principle governing the application to the members of the armed forces of these guarantees and the extent to which they shall apply to persons in this category shall equally be determined by national laws or regulations.

Article 6 of Part II of the same Act provides that:

With a view to ensuring the effective exercise of the right to bargain collectively, the Contracting Parties undertake:

a) to promote joint consultation between workers and employers

b) to promote, where necessary and appropriate, machinery for voluntary negotiations between employers or employers' organisations and workers' organisations, with a view to the regulation of terms and conditions of employment by means of collective agreements

c) to promote the establishment and use of appropriate machinery for conciliation and voluntary arbitration for the settlement of labour disputes

and recognise:

d) the right of workers and employers to collective action in cases of conflicts of interest, including the right to strike, subject to obligations that might arise out of collective agreements previously entered into.

These documents were recognised by the Single European Act 1987 as forming the foundations of the European Community. Article 6 of the Treaty on the European Union stressed that the Union must respect the fundamental rights recognised by the European Convention on Human Rights, while Article 136 (as amended by the Treaty of Amsterdam) stresses the fundamental social rights as had been set out in the European Social Charter of 1961.

The European Court of Justice has vast case law which has made it clear that, in the process of enacting EU legislation, EU institutions are obliged to respect fundamental human rights, including those prescribed by the ECHR. 
The European Community itself expressly recognises the right of workers to association and to join trade unions:

Employers and workers of the European Community shall have the right of association in order to constitute professional organisations or trade unions of their choice for the defence of their economic and social interests. Every employer and every worker shall have the freedom to join or not to join such organizations without any personal or occupational damage being thereby suffered by him.

The EU Charter on Fundamental Rights (which, by virtue of the Lisbon Treaty, obtained the same legal status as the Treaties) states that everyone has the right to freedom of peaceful assembly and freedom of association at all levels, in particular in political, trade union and civic matters, which implies the right of everyone to form and join trade unions for the protection of his or her interests.

Workers also have the right to collective bargaining, and the EEC Treaty of 1957 had already provided for the input of the social partners - employers, workers and different sectoral interests - to be recognised in the Economic and Social Committee, as well as their right to take part in the legislative process. That is, they had the right to be consulted regarding the contents and outline of the social and economic legislation of the Community. Under the European Employment Strategy, the role of the social partners was significantly augmented to one of legislators and partners in change.

In addition to this formal input in the process of the making of the legislation of the EU, the trade unions are involved in active lobbying of the key political groups in the European Parliament, European Commissioners and the Council of Ministers. However, umbrella organisations like the ETUC are frequently internally divided on measures regarding the workplace and often, wisely, do not take specific stands. On the contrary, they could become a loser in the best scenario but bounce back in the worst. ${ }^{1}$

Collective bargaining refers to bipartite or tripartite negotiations relating to labour problems and eventually leading to the resolution of certain labour-employer problems or to the conclusion of agreements.

In the then EEC in 1985, the so-called Val Duchesse inter-sectoral social dialogue between the European Trade Union Confederation (ETUC), the Union of Industrial and Employer Confederations of Europe (representing employers from the private sector) and the European Centre of Public Enterprises (UNICE) was initiated.

The Single European Act in 1987 introduced Article 118b which facilitated the endeavour to develop dialogue between management and labour which could lead to relations based on agreement. The EEC Social Charter, on the other side, provided that dialogue between the two sides of the industry must be developed and that this may, if the parties deem it desirable, result in contractual relations in particular at the interoccupational and sectoral level. ${ }^{2}$ However, these were more political than legal obligations. Even so, this provision re-launched the Val Duchesse dialogue, which led to

1 Van Schendelen, R (2006) Machiavelli in Brussels: The Art of Lobbying the EU $2^{\text {nd }}$ Ed. Amsterdam University Press, p. 184.

2 Article 12(2) of the Social Charter, 1989. 
the adoption of the European Social Charter in 1989 and the conclusion of a joint agreement, presented at the Inter-Governmental Conference in Maastricht and transposed in Articles 3 and 4 (new Article 138 and 139) of the Agreement on Social Policy by the Treaty on the European Union. This Agreement provided the right of consultation of the social partners on the relevant EC legislation and to enter into dialogue in order to reach agreements that could be implemented autonomously or by a Council Directive.

These actions strengthened collective bargaining at the EU level and led to intensive bargaining in national frameworks. The EU's role for social partners is one of partnership and co-operation. The EU's social directives, such as the Directive on proof of the employment contract, working time and young workers can now be implemented by collective bargaining. National authorities are obliged to take the necessary measures on implementation or should ensure that employer and worker representatives introduce the required provisions by way of agreement. Collective agreements, or their equivalents, can be used for implementing the substantive standards of directives.

However, developments at the level of the EU up to now have not led to the forming of an EU-wide trade union. This is due to multi-dimensional differences between the trade union movements in different member states. For instance, in some member states the trade unions are unified (as in the UK, Germany, Ireland, etc.), whereas in others they reflect that country's political and ideological divisions: Catholic and noncatholic; communist and anti-communist; collectivist and individualist (as in Italy); or on the basis of the different languages being spoken between different communities. Given the lack of such uniting EU-wide interests and driving forces, it is very unlikely on present terms that an EU-wide trade union will be formed, and co-operation will continue through the European Trade Union Confederation. ${ }^{3}$

The ETUC was formed in 1973 in order to promote the interests of working people in European institutions. The growing impact of EU legislation and its penetration into every detail of everyday life, including at work, has significantly changed the environment in which trade unions operate. To influence the content of EU legislation, they must represent their interests within a single voice. Furthermore, the ETUC has the ambition of forming a pan-European single trade union movement. For these purpose, a large number of trade unions from central and east European countries have already joined this association. The ETUC is recognised by the European Union as one of the European social partners and is involved in the social dialogue at European Union level with employers. It is represented on the consultative bodies and committees of the various institutions of the European Union (such as the Economic and Social Committee). In the process of co-operation, the European social partners have so far adopted more than forty cross-industry and 500 sectoral joint texts. ${ }^{4}$

ETUC keeps its membership informed on their rights to information and consultation, as well as the right to participate in decision-making processes in undertakings. For example, under the European Works Council Directive, over ten million workers through their EWC may influence the course of decision-making in their companies

3 Barnard, C (2012) EU Employment Law New York: Oxford University Press, p. 708.

$4 \mathrm{http}: / /$ www.etuc.org/r/20. 
provided that the company has more than 1000 employees, of which there are at least 150 workers in two or more member states. The first EWC Directive was adopted in 1994 and, as a result of intensive campaigning by the ETUC and European trade union federations, the Council and the European Parliament adopted a recast directive on EWCs in 2009 (which has been in force since 2011). ${ }^{5}$

Under Article 1:

A European Works Council or procedure for informing and consulting employees shall be established in every Community-scale undertaking and every Community-scale group of undertakings, where requested in the manner laid down in Article 5(1), with the purpose of informing and consulting employees. The arrangements for informing and consulting employees shall be defined and implemented in such a way as to ensure their effectiveness and to enable the undertaking or group of undertakings to take decisions effectively.

Information and the consultation of employees must occur at the relevant level of management and representation, according to the subject under discussion. To achieve that, the competence of the European Works Council and the scope of the information and consultation procedure for employees governed by this Directive shall be limited to transnational issues. ${ }^{6}$

Responsibility for the establishment of a works council, or a consultation and information procedure, lies with the central management of the undertaking. The procedure for establishing an European Works Council or an information and consultation procedure can be initiated by central management or on the written request of at least one hundred employees or their representatives in at least two undertakings or establishments in at least two different member states. ${ }^{7}$

For this purpose, a special negotiating body is formed consisting of representatives of workers. Member states enjoy discretion in determining the route of the election or appointment of the members of the special negotiating body with regard to their respective territory, so it can be expected that, in the same enterprise that has subsidiaries in two or more different member states, the procedures for appointment may be different. Also, member states shall provide that employees in undertakings and/or establishments in which there are no employee representatives, through no fault of their own, have the right to elect or appoint members of the special negotiating body. The central management and the special negotiating body are tasked to open negotiations with a view to concluding an agreement on the detailed arrangements for implementing the information and consultation of employees.

The agreement should inter alia address the following issues:

- scope of the undertakings of the Community-scale group of undertakings or establishments of the Community-scale undertaking

- the composition of the European Works Council

5 Directive 2009/38/EC of the European Parliament and of the Council of 6 May 2009 on the establishment of a European Works Council or procedure in Community-scale undertakings and Community-scale groups of undertakings for the purposes of informing and consulting employees, Official Journal L122, 16 May 2009.

6 Emphasis added.

7 Article 5(1). 
- the functions and the procedure for information and consultation of the European Works Council, as well as arrangements for linking the information and consultation of the European Works Council with national employee representative bodies

- the venue, frequency and duration of meetings of the European Works Council

- where necessary, the composition, appointments procedure, the functions and the procedural rules of select committees set up within the European Works Council

- the financial and material resources to be allocated to the European Works Council

- the date of entry into force of the agreement and its duration, etc.

There is a possibility for the central management and the special negotiating body to agree to establish one or more information and consultation procedures instead of a European Works Council. ${ }^{8}$

There is an obligation on both the central management and the European Works Councils, as well as employee representatives within the framework of the consultation and information procedure, to work in a spirit of co-operation with due regard to their reciprocal rights and obligations. ${ }^{9}$

Under the Directive, the members of the European Works Council shall have the resources required to apply the rights arising from this Directive, i.e. to represent collectively the interests of the employees of the Community-scale undertaking or Community-scale group of undertakings.

The members of European Works Councils are obliged to inform the representatives of employees of the establishments or of the undertakings of a Community-scale group of undertakings (or, in the absence of representatives, the workforce as a whole) of the content and outcome of the information and consultation procedure.

Members of the special negotiating bodies, members of European Works Councils and employees representatives in the information and consultation procedure should enjoy protection and guarantees similar to those provided for employee representatives in national legislation and/or practice in force in their country of employment. This is in particular with regard to attendance at necessary meetings and to the payment of wages for members who are on the staff of the Community-scale undertaking or the Community-scale group of undertakings. ${ }^{10}$

The ETUC has also a research and innovative role via its European Trade Union Institute. Its branches conduct scientific research on socio-economic issues and industrial relations, and its results are presented and used by the ETUC itself. The ETUI Education Department promotes the European dimension of the trade union movement. Similarly, the ETUI's Working Conditions and Health and Safety Department monitors the national incorporation and implementation of European legislation regarding workers' health and safety. This Department assists the EU institutions and provides expertise in areas like safe conditions of work, health conditions and many other issues related to workers' rights and freedoms.

8 Article 6(3).

9 Article 9.

10 Article 10. 
Being involved in the creation of the relevant EU legislation regarding these conditions, the ETUC at the same time monitors its application and adequate transposition at the national level and, if necessary, warns the EU institutions of any existing or potential problem areas.

The ETUC is very active in protecting and standing up for workers' rights. Its recent activities include, for instance a mobilisation on 29 February 2012 right across Europe to stress that solutions to the current crisis in EU do exist other than in terms of budgetary discipline. The ETUC stressed the need for a recovery plan for employment and sustainable growth. The ETUC stands up against the cutting of wages and social protection, the attack on collective bargaining mechanisms and making employment contracts ultra-flexible according to the wishes of the neo-liberal ideologists. This is why the ETUC has stressed that social justice and employment must be top priorities in these tough times.

In 2011, the ETUC held several demonstrations mainly against austerity measures in several European countries. On 17 September 2011 in Wrocław, Poland, a Eurodemonstration was organised with the support of the Polish trade union confederations, Solidarność and OPZZ. The aim of this mobilisation was to assert trade union opposition to the attack on trade union rights and collective bargaining and to austerity measures. Similarly, a few days before the June summit of the European Council on 21 June 2011 in Luxembourg, demonstrations were held against austerity measures and in order to show trade union opposition to the Euro Plus Pact and its serious implications for pay, social security and collective bargaining. ${ }^{11}$ When on 9 April ECOFIN held its meeting in Budapest, the ETUC again took action, in order to ensure that the voice of European workers was heard as well as their alternative proposals on the proposed austerity measures and fiscal consolidation plans targeted at the reduction of public expenditure, public services, workers' wages and distortions in the collective bargaining process and dialogue between the social partners. ${ }^{12}$

On 24 March 2011, trade union demonstrations and rallies took place within the framework of the European Day of Action decided on by the ETUC. Again, coinciding with the European Summit of 24-25 March, the ETUC intended this action to say 'no' to austerity plans in Europe, cuts in wages and pensions, insecurity, unemployment, the deregulation of labour standards and social regression, and to rising social inequalities. $^{13}$

All in all, the trade unions and their associations at European level have a long tradition in protecting workers' rights and a series of developed instruments and channels for exercising influence over the decision-making process as well as the means for exercising protest.

\section{The role of trade unions in Macedonia, Serbia and Croatia}

The right to found trade unions in order to protect workers' economic and social rights is guaranteed by Article 37 of the Constitution of the Republic of Macedonia.

11 http://www.etuc.org/a/8776.

12 http://www.etuc.org/a/8313.

13 http://www.etuc.org/a/8439. 
Trade unions can also form associations and join international trade union organisations. The only exceptions with regard to restrictions on freedom of association concerns the police force, the armed forces and public administration. The right to strike is also guaranteed, with the same restricted groups.

Similar provisions are contained in Articles 59 an 60 of the Croatian Constitution.

In comparison, the Constitution of Serbia does not contain a comparable clause with regard to trade unions. Article 82(3), for instance, speaks of an:

Alignment of the impact of the market economy on the economic and social position of working people through social dialogue between trade unions and employer associations.

Article 61 contains a somewhat more restrictive right of strike of workers 'in accordance with law and collective agreement.' Restrictions in Serbia on the right to strike, with regard to the nature and type of activity, can only be imposed by law.

More detailed provisions are contained in the Law on Labour Relations of Macedonia. For instance, trade union membership is voluntary and every worker can freely join or leave membership of the union. A trade union can not be banned in an administrative process if it acts in accordance with the law, and neither in the same way can its members be dismissed. ${ }^{14}$

Members of trade unions have a right to judicial protection in the event of any infringement of their rights stipulated by statute or other acts of the trade union. ${ }^{15}$ Workers who are members of the trade union can not be put in a disadvantaged position due to their trade union membership, ${ }^{16}$ especially in circumstances where the contract of employment is conditioned by non-membership of a trade union or on the condition that the worker leaves the union. Also, the contract of employment can not be terminated or the worker jeopardised in another way either on the grounds of his or her membership of a union, or for taking part in the activities of a trade union. There is also a ban on the employer, manager or their representative to use any coercive measures against trade unions. ${ }^{17}$

Representatives of trade unions also enjoy protection under the Law. Consequently, their contracts of employment cannot be terminated, nor their wages reduced, on grounds of their trade union membership or activities. Protection from the termination of the contract of employment lasts two years after the expiry of the term of office. ${ }^{18}$

The corresponding Croatian Law on Labour does not contain more detailed provisions on the establishment nor activities of trade unions.

The Serbian Law on Labour Relations proclaims that the freedom to form trade unions and to participate in their activities without prior authorisation is guaranteed. ${ }^{19}$ Trade unions have the right to be informed about economic and social issues

Article 186, Labour Relations Law of Republic of Macedonia.

Article 197.

Article 185.

Article 198.

Article 200.

Article 205, Law on Labour of Republic of Serbia. 
relevant to the economic and social position of the trade union. ${ }^{20}$ There is also an obligation on the employer to provide appropriate technical conditions and facilities as well as adequate access to information essential for trade union activities. ${ }^{21}$

Representatives of the trade union have the right to paid absence from work for performing their duties, especially if they are involved in negotiations for concluding collective agreements or in court or arbitration proceedings.

The trade union representative has, according to the Law, the right to at least forty hours of paid work per month if the union has at least two hundred members, and an additional one hour for every additional one hundred members. The proportion of paid hours decreases proportionally if the number of members of the union is less than two hundred. ${ }^{22}$

Interestingly, the Macedonian Law on Labour Relations contains the possibilities of the restriction of the constitutionally-guaranteed right to strike, at the request of the employer, and a ban may be imposed by a competent court. ${ }^{23}$ This was recently done by Basic Court 2 in Skopje which, at the request of the Ministry of Health, imposed a ban on an announced strike by the trade unions of doctors employed in the Clinical Centre in Skopje. ${ }^{24}$

Under the same Law on Labour Relations in Macedonia, it is possible for the work of the trade union to be banned by the courts if it acts in contravention of the Constitution or the Law. ${ }^{25}$ These procedures under the law can be initiated by the registration office or by a competent court. ${ }^{26}$ These restrictions, accompanied by dozens of other changes to the Law on Labour Relations, makes it extremely difficult for workers to organise strikes in Macedonia, vis- $\grave{a}$-vis the extremely liberal guarantee of the right to strike provided by the Constitution. This makes the exercise of this right practically impossible; interestingly, however, these restrictions on the right to strike were passed by parliament without any significant unrest or protests by the trade unions.

Perhaps, this may be put down to Macedonian ruling parties, subsequent to separation from Yugoslavia, having always tried to control the trade unions and succeeding in doing so most of the time. So far, all the leaders of the largest Association of Trade Unions in Macedonia (the SSM) have been close to the ruling party at a given period of time.

There are no comparable possibilities for restricting the right to strike or the activities of trade unions in the comparative Serbian and Croatian laws. Interestingly, the 2012 Progress Report by the European Commission on Serbia notes that the Law on Strikes from 1996 is not in line with EU and ILO standards, that the social dialogue is

20 Article 209.

21 Article 210.

22 Article 211.

23 Article 202.

24 http://www.time.mk/read/e56caff5e3/4857b8alea/index.html.

25 Article 202.

26 The Law here contradicts the elementary principles of ne procedat iudex ex officio (no court is empowered to initiate legal proceedings on its own account) and nemo iudex sine actore (no judgment may be made without an accuser). 
limited; and that the Economic and Social Council is not consulted on laws while government representatives do not attend its meetings. ${ }^{27}$ The Macedonian Progress Report for 2012 notes that the bipartite social dialogue remains weak and that the position of the trade union is weak due to the lack of stable finances and the gaps in management capacity. $^{28}$

Similarly, trade unions in Croatia and Serbia have, in the face of the current situation, been as lethargic as in Macedonia, with no record of mass or continuous general strikes such as, for instance, strike activity in Spain, Italy or Greece. However, in Serbia and Croatia the most recent activities show signs of the trade unions not being so passive. For instance, in Serbia, in reaction to the recent upsurge of prices due to the increase in VAT (without any prior review of the situation and position of workers, as had been promised by the Prime Minister in the Economic and Social Council), the SSSS trade union confederation presented an ultimatum that massive street demonstrations would be held by the end of October if prices were not returned to the previous level, since purchasing power, especially among the most vulnerable categories of the population, had dropped rapidly. ${ }^{29}$ In Croatia, massive demonstrations were held in Zagreb on 12 October 2012, because of the cuts in teachers' and professors' wages, after workers in these branches refused to sign the proposed New Basic Collective Agreement with the government. Around 10000 workers participated in the demonstrations. $^{30}$

In contrast, in Macedonia there have been no reactions to the upsurge of prices in the past two months by the trade unions, nor have there been any threats to organise demonstrations. However, there was one interesting phenomenon: Civic Initiative 'Aman' organised symbolic protests in several Macedonian towns in order to give impetus to the wider public to protest against the rapid drop in living standards and in working conditions. The protests were also intended to show the trade unions that they were not carrying out their functions of protecting workers' rights. ${ }^{31}$ Only one branch of SSM, the largest Macedonian trade union, expressly supported the demonstrations (UPOZ), while the leader of SSM refused any support. This was perhaps due to the overly-strong influence of the government on SSM.

\section{Conclusion}

This brief comparison of the role and position of the trade unions in the European Union on the one hand and trade unions in Macedonia, Serbia and Croatia on the other shows certain similarities, but also significant differences between them.

At European level, co-operation between trade unions dates back almost forty years and is well-established enough first of all to influence formal processes of decisionmaking by representation in one of the consultative bodies of the European Union (the

31 Personal interview with Zdravko Saveski, informal leader of Civic Initiative 'Aman', 16 October 2012. 
Economic and Social Council); however, they represent workers' interests (even more) through informal channels via direct lobbying of the European Commission, the European Parliament and the Council of Ministers. Recent activities regarding the austerity measures taken in most EU member states show that national trade unions and the ETUC act in co-ordination in order to influence decision-makers to review alternative measures, because the vast part of those measures already taken are being felt mostly by workers right across the EU. The activities of the ETUC are developed to the extent that it conducts academic studies on socio-economic issues and industrial relations, on education and on the trade union movement.

At the same time, this short comparative analysis shows that the dominant trade unions in Macedonia, Serbia and Croatia, or their leaders, continue to have close ties to ruling parties, keeping workers' voice and activities under control. This makes them weak and incapable of asserting a more serious influence on the decision-making process. The situation is probably worst in Macedonia where the trade unions are practically 'toothless', showing practically no, or only insignificant, resistance to the continuous reduction in workers' rights by the government and parliament in correspondence with employer associations. ${ }^{32}$ Another problem in Macedonia is the tendency to over-regulate the constitutionally-guaranteed rights to form trade unions and the right to strike to a degree that makes these rights hard, or even impossible, to exercise. Furthermore, under Macedonian laws there is the possibility of banning a strike via a court order or the activities of the trade union itself. Such restrictions were not noted either in Serbia or in Croatia, so the position of trade unions there can be concluded to be less restrictive than in Macedonia. Another problem in Macedonia is the very frequent changes to labour relations laws, which inevitably has an impact on the legal certainty of workers. This is also not the case in Serbia and Croatia.

\section{References}

Directive 2009/38/EC of the European Parliament and of the Council of 6 May 2009 on the Establishment of a European Works Council or procedure in Communityscale undertakings and Community-scale groups of undertakings for the purposes of informing and consulting employees Official Journal L122 16/05/2009.

Barnard, C (2012) EU Employment Law New York: Oxford University Press, p. 708. Constitution of the Republic of Macedonia.

Constitution of the Republic of Serbia.

Constitution of the Republic of Croatia.

Labour Relations Law of Republic of Macedonia, downloaded from: www.pravo.org.mk

Labour Relations Law of Serbia, downloaded from: http://www.svos.org.rs/pdfs/zakon_o_radu.pdf.

Labour Relations Law of Croatia Narodne novine 149/09, 61/11, 82/12.

32 See: Saveski, Z (Ed.) (2011) The Strike: Experiences and Conditions Lenka: Skopje, pp. 109-113. 
Saveski, Z (Ed.) (2011) The Strike: Experiences and Conditions Lenka: Skopje. Social Charter of EEC, 1989.

van Schendelen, R (2006) Machiavelli in Brussels: The Art of Lobbying the EU 2nd Ed., Amsterdam University Press.

http://www.time.mk/read/e56caff5e3/4857b8a1ea/index.html.

www.shu.hr.

www.sindikat.rs/ENG/news.html\#43.

http://www.time.mk/read/e56caff5e3/4857b8alea/index.html. 